\title{
A Study of Learning Physical Fitness Activities Based on Traditional Balinese Sports Games for Students' Physical Fitness
}

\author{
I Ketut Hendry Wijaya Kusuma ${ }^{1,2, *}$, Moch. Asmawi ${ }^{1}$, Hernawan', Firmansyah Dlis ${ }^{1}$, \\ Widiastuti ${ }^{1}$, I Nyoman Kanca ${ }^{2}$ \\ ${ }^{1}$ Faculty of Teaching and Education, State University of Jakarta, 13220, Jakarta, Indonesia \\ ${ }^{2}$ Faculty of Teaching and Education, Universitas Pendidikan Ganesha, 81116, Bali, Indonesia
}

Received May 1, 2021; Revised August 11, 2021; Accepted September 8, 2021

\section{Cite This Paper in the following Citation Styles}

(a): [1] I Ketut Hendry Wijaya Kusuma, Moch. Asmawi, Hernawan, Firmansyah Dlis, Widiastuti, I Nyoman Kanca , "A Study of Learning Physical Fitness Activities Based on Traditional Balinese Sports Games for Students' Physical Fitness," International Journal of Human Movement and Sports Sciences, Vol. 9, No. 5, pp. 1029 - 1039, 2021. DOI: 10.13189/saj.2021.090525.

(b): I Ketut Hendry Wijaya Kusuma, Moch. Asmawi, Hernawan, Firmansyah Dlis, Widiastuti, I Nyoman Kanca (2021). A Study of Learning Physical Fitness Activities Based on Traditional Balinese Sports Games for Students' Physical Fitness. International Journal of Human Movement and Sports Sciences, 9(5), 1029 - 1039. DOI: 10.13189/saj.2021.090525.

Copyright@2021 by authors, all rights reserved. Authors agree that this article remains permanently open access under the terms of the Creative Commons Attribution License 4.0 International License

\begin{abstract}
The implementation of traditional game-based learning aimed at improving students' physical fitness is very important to do. Therefore, the purpose of this study was to determine the comparison of learning physical fitness activities based on traditional Balinese sports games for the physical fitness of students in junior high schools in Denpasar City. This study used a survey research design using a quantitative approach with a comparative descriptive design. Where, the sample in this study amounted to 200 junior high school students obtained based on cluster sampling technique. The instrument used was the ACSPFT test for junior high school students. The data analysis used includes descriptive statistics (mean, min, max, category) and inferential statistics using MANOVA followed by the Poshoc Tukey test and independent sample t-test. The integration of local wisdom in this case is traditional games in learning very well, in addition to strengthening and introducing local culture, integrating traditional games into learning will make it easier for teachers to teach the learning they want to teach, especially in Physical Education subjects. Physical education is very compatible with the character of traditional games that make children play, which contains elements of cognitive, affective, psychomotor. Moreover,
\end{abstract}

Physical Education for junior high schools in its implementation must generate student interest in learning Physical Education, so one of the learning methods is by using traditional games. Traditional games can be used as an alternative in junior high school physical education. Because traditional games contain elements of play, they are not bound by many rules such as competition which will improve students' physical fitness. Due to the physical fitness of students will be formed, if physical activity is carried out continuously for a long time and is sustainable.

Keywords Physical Fitness, Traditional Game-Based Activity Learning, ACSPFT Test

\section{Introduction}

Education is a field that plays the most important role in developing Indonesian people as a whole. The essence of development in the field of education is so that the Indonesian nation becomes intelligent, skilled and has noble character, and is physically and mentally healthy [1-4]. Education in Indonesia is directed and aimed at 
realizing a just, prosperous and equitable society both materially and spiritually which is carried out by increasing the quality of quality human resources. Physical education includes subjects in school as a medium that encourages motor development, physical abilities, knowledge of reasoning, appreciation of values (attitude, mental, emotional, spiritual, social), helps students understand why humans move and how to move safely, efficiently, effective so as to appreciate the benefits of physical activity for improving the quality of life and habituation of a healthy lifestyle which leads to stimulating balanced growth and development [5-7].

Physical education is an educational effort using large muscular activity so that the ongoing educational process is not hampered by health problems and body growth. As an integral part of the whole educational process, physical education is an effort that aims to develop an organic, neuromuscular, intellectual and social area [8, 9]. Because movement as a physical activity is a basic movement for humans to get to know the world and themselves which naturally develop in line with the development of the times. One of the goals of physical education is to form a qualified human being, physically and mentally healthy. Along with the development of science and technology which is oriented towards the goal of human being physically and mentally healthy. Physical education is a part of education designed to develop total student potential through physical activities and physical experiences. This means that physical education is an integral part of education which has a positive impact not only on physical growth, but also mental and intellectual development, emotional and social. According to Firmansyah, physical education is a core component of quality education and an intergaral part of lifelong learning $[10,11]$. In the physical fitness material, there are components that are taught in accordance with the basic competencies that have been provided by the government. Basic competence is intended as a benchmark for students in carrying out the learning process. In school learning, physical education and sports learning hours are sometimes used for other activities or used by teachers in other fields of study. Even if physical education learning and sports taught in schools do not seem to be carried out effectively, this is confirmed by Kanan and Gzagzah's research which shows that there is a lot of time wasted in learning physical education and sports, teachers spend $31.9 \%$ of their time studying explanation of lesson time on class management, and $11.9 \%$ on organizing activities. This study also showed that the average time spent by students practicing physically was about $9.5 \%$ of all lessons [12].

The low level of physical fitness of students in schools from all levels of education units in Indonesia can be used as a general indication that the quality of physical education programs in Indonesia is still low. The survey results from the Sport Development Index development team stated "that almost $80 \%$ of Indonesians have poor physical fitness and then this affects the development of sports which is still very low" [13]. Based on the results of research conducted by I Ketut Yoda [14], the level of physical fitness of class XI and XII students of SMA Negeri 4 Singaraja Buleleng Bali in the 2008/2009 academic year was classified as very low (64\%). Only $2 \%$ of the students' physical fitness level is good. The low level of physical fitness can be caused by the development of technology that affects the physical fitness of each individual, especially among children. Physical inactivity and obesity among children and adolescents have become a global public health concern because they negatively impact the health, well-being and growth of children [15].

The learning process that takes place from the observations of researchers at several State Junior High Schools in Denpasar has not been maximal in the implementation of learning, especially when presenting physical fitness material or other material. Teachers still use conventional models, the lack of application of learning models that involve more students in the learning process, which results in students being silent and less active, so that learning looks monotonous in carrying out motion activities [16-19]. The development of learning materials in the form of a learning model during the physical fitness learning process according to the teacher can improve the physical fitness of students through the pattern of developing learning materials. The process of implementing learning materials using the learning model given to students so that they can respond, so that teachers can pay attention to the shortcomings that occur in students during learning [20]. Each student has a different level of needs and skills, so that during the learning process students who have difficulty completing the task of the learning material must complete the task, even though they actually realize that they cannot complete the task [21, 22]. Therefore, we need a learning model of development activities (physical fitness) based on traditional Balinese games which is an attraction in order to increase students' understanding in training their physical fitness, especially on strength and endurance.

Increasing physical fitness is one of the actualizations of learning activities in order to support the creation of learning objectives. Coaching to improve physical fitness in students, namely Strength (Streng). Endurance, Mascular Power, Speed, Flexebility Agility, Coordination, Balance, Accuracy, Reaction [23- 26]. Physical fitness can be defined as the ability to carry out daily activities without feeling excessively tired and still have reserves of energy to enjoy free time and activities that are sudden in nature. Physical freshness is a condition of physical fitness that is related to the ability and ability to function in an optimal and efficient manner. Whether we realize it or not, physical fitness is actually one of the necessities of human life because physical fitness is compounded by human life. Physical freshness can characterize the quality of human life. Physical fitness indicates the ability to 
fulfill its duties satisfactorily and the ability of the circulatory respiratory system to recover from its original workload [27, 28].

Endurance In this case, there are two types of endurance, namely: 1) Cardiovascular Endurance (Cardiovascular Endurance) Cardiovascular endurance Is the ability of the heart, lung and blood vessel systems to function optimally during rest and work in taking oxygen and channeling to active tissues, so that it can be used in the body's metabolic processes [29, 30]. This is necessary to support muscle work. Cardiovascular endurance is the most important component of physical fitness and is often used as a synonym for physical fitness [31]. Cardiovascular endurance is influenced by heredity (genetic), age, gender and physical activity. 2) Muscle Endurence (Muscle Endurence) Muscle endurence is the ability of a person to use his muscles to contract continuously for a relatively long time with a certain load [32]. The ability of a person to use their muscles to contract regularly for a relatively long time with a certain load.

Therefore, the researcher aims to determine whether there is a significant difference to the physical fitness of students in implementing physical fitness activity learning based on traditional Balinese game sports.

\section{Materials and Methods}

This research is a survey research. According to Cohen,
Manion, and Morrison [33], the survey is part of a descriptive method that aims to look for positions (status), phenomena (symptoms) and determine the similarity of status by comparing them with predetermined standards. This research design uses a quantitative approach with a comparative descriptive design. According to Creswell [34], comparative research is research that compares two or more symptoms. Descriptive comparatives compare the same variables for different samples.

The subjects in this study were taken from four junior high schools in the city of Denspasar as many as 200 students, with details of 50 students of SMP Negeri 1 Denpasar with details of 24 male students and 26 female students, 50 students of SMA Negeri 3 Denpasar with details of 24 male students and 26 female students, 50 students of SMP 8 Denpasar with details of 24 male students and 26 female students, and 50 students of SMP Negeri 9 Denpasar with details of 24 male students and 26 female students. Sampling based on cluster sampling technique. In cluster sampling two or more elements or two or more units are included in the sample at each sample location [35]. The inclusion of two or more units / elements at each sample location increases the sampling effort at each sample location. Cluster sampling was chosen because it can facilitate research to collect data from a large research area.

The data collection procedure referred to in [34], is described in figure 1 below:

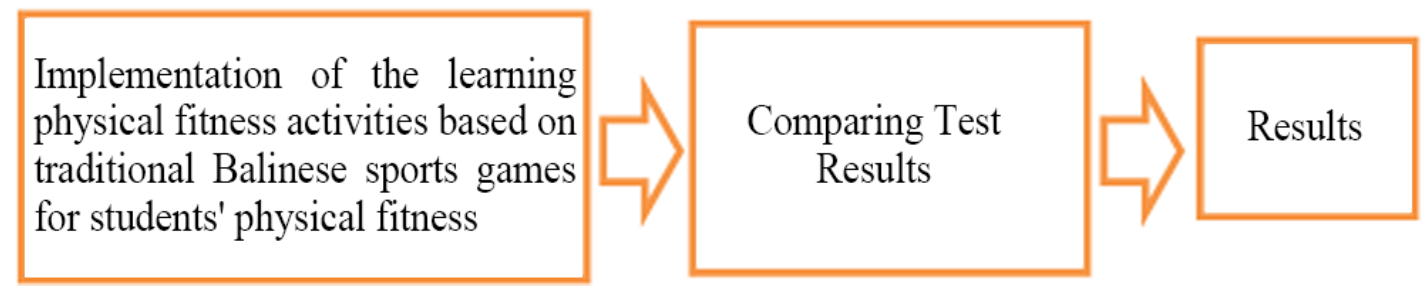

Figure 1. Data Collection 
The first thing to do is to apply learning physical fitness activities based on traditional Balinese sports games to get students' physical fitness. After learning activities based on traditional Balinese sports games were measured using the A.C.S.P.F.T test instrument for junior high school students. ACSPFT is a branch of an international organization whose target activities are to compile and standardize various forms of physical fitness tests called ICSPFT (International Committee on the Standardization of Physical Test). In Asia, on the initiative of Asian countries, a common organization has been formed and is a subsidiary of I.C.S.P.F.T, whose activities are aimed at Asian countries and nations. The organization is named: ACSPFT (Asia Committee on the Standardization of Physical Test). A.C.S.P.F.T Physical Fitness Test for Junior High School Students / STLA / Students / Taruna includes; 1) $50 \mathrm{~m}$ fast run; 2) Long jump without prefix; 3) hanging lift for men and hanging elbow bending for women; 4) Running back and forth $4 \times 10 \mathrm{~m}$; 5) Lie down for 30 seconds; 6) Loosen the togok to the mouth; 7) Long run, $1000 \mathrm{~m}$ for men. $800 \mathrm{~m}$ for girls. The use of the A.C.S.P.F.T test instrument is intended to determine the physical fitness of students which includes strength and endurance. Why only strength and endurance are the main topics in this study, because strength and endurance are the main bases in students' physical fitness. The factor of strength (maximum strength), including muscle power or explosiveness (combination of strength and speed), and muscle endurance and cardiorespiration, both anaerobic and aerobic, are elements of physical fitness (biomotor abilities) that need to be considered by an athlete. [35-37]. After the data is collected then the data is compiled, then the data is processed with descriptive statistics which include meana, min, max, and categories as well as inferential statistics using MANOVA analysis with Tukey's poshoc advanced test.

Based on A.C.S.P.F.T. (Asian Committee for the Standardization of Fitness Tests) measurement results are put into the following categories:

Table 1. Physical fitness norms for female students

\begin{tabular}{|c|c|}
\hline Score & Classification \\
\hline $441-$ to the top & Very Good \\
\hline $361-440$ & Good \\
\hline $281-360$ & Enough \\
\hline $201-280$ & Not Good \\
\hline $000-200$ & Very Not Good \\
\hline
\end{tabular}

(Sources: A.C.S.P.F.T. 1977, 31)

Table 2. Physical fitness norms for male students

\begin{tabular}{|c|c|}
\hline Score & Classification \\
\hline $431-$ ke atas & Very Good \\
\hline $376-430$ & Good \\
\hline $311-375$ & Enough \\
\hline $251-310$ & Not Good \\
\hline Ke bawah -250 & Very Not Good \\
\hline
\end{tabular}

(Sources: A.C.S.P.F.T. 1977, 31)

\section{Results and Discussion}

The research findings are described in this section. For the results of the A.C.S.P.F.T test to see the physical fitness of students can be seen (table 3-6) below.

Table 3. Results of physical fitness of SMP 1 Denpasar students

\begin{tabular}{|c|c|c|c|c|c|c|}
\hline \multicolumn{4}{|c|}{ Category Female } & \multirow{2}{*}{ Mean } & \multirow{2}{*}{ Min } & \multirow{2}{*}{ Max } \\
\hline Response & Range & $\mathbf{F}$ & $\%$ & & & \\
\hline Very Good & 441 - to the top & 1 & 3.8 & \multirow{5}{*}{338.5} & \multirow{5}{*}{270} & \multirow{5}{*}{443} \\
\hline Good & $361-440$ & 10 & 38.6 & & & \\
\hline Enough & $281-360$ & 11 & 42.3 & & & \\
\hline Not Good & $201-280$ & 4 & 15.3 & & & \\
\hline Very Not Good & $0-200$ & 0 & 0.0 & & & \\
\hline \multirow[t]{2}{*}{ Total } & & 26 & 100 & & & \\
\hline & ategory Male & & & \multirow{2}{*}{ Mean } & \multirow{2}{*}{ Min } & \multirow{2}{*}{ Max } \\
\hline Response & Range & $\mathbf{F}$ & $\%$ & & & \\
\hline Very Good & 431 - to the top & 4 & 16.7 & \multirow{5}{*}{398.7} & \multirow{5}{*}{307} & \multirow{5}{*}{435} \\
\hline Good & $376-430$ & 10 & 41,7 & & & \\
\hline Enough & $311-375$ & 8 & 33.3 & & & \\
\hline Not Good & $251-310$ & 2 & 8.3 & & & \\
\hline Very Not Good & $0-250$ & 0 & 0.0 & & & \\
\hline Total & & 24 & 100 & & & \\
\hline
\end{tabular}


From table 3, which came from 50 respondents from the junior high school 1 Denpasar after they were obtained and the results using the SPSS 23 application program, the physical fitness of female students was in the dominant category quite good with a percentage of $42.3 \%$ (11 out of 26 students) and has a mean value of 338.5, a minimum score of 270, and a maximum score of 443 . As for the male students physical fitness is in the dominant good category with a percentage of $41.7 \%$ (11 of 24 students) and has a mean value of 398.7, a minimum score of 307 , and a maximum score of 435 .
From table 4, which came from 50 respondents from the junior high school 3 Denpasar after they were obtained and the results using the SPSS 23 application program, the physical fitness of female students was in the dominant category quite good with a percentage of $46.2 \%$ (12 of 26 students) and has a mean value of 332.5, a minimum score of 278, and a maximum score of 445 . As for the male students physical fitness is in the dominant good category with a percentage of $50.0 \%$ (12 of 24 students) and has a mean value of 399.2, a minimum score of 304 , and a maximum score of 437 .

Table 4. The results of physical fitness of SMP 3 Denpasar students

\begin{tabular}{|c|c|c|c|c|c|c|}
\hline \multicolumn{4}{|c|}{ Category Female } & \multirow{2}{*}{ Mean } & \multirow{2}{*}{ Min } & \multirow{2}{*}{ Max } \\
\hline Response & Range & $\mathbf{F}$ & $\%$ & & & \\
\hline Very Good & 441 - to the top & 1 & 3.8 & \multirow{5}{*}{332.5} & \multirow{5}{*}{278} & \multirow{5}{*}{445} \\
\hline Good & $361-440$ & 9 & 34.6 & & & \\
\hline Enough & $281-360$ & 12 & 46.2 & & & \\
\hline Not Good & $201-280$ & 4 & 15.4 & & & \\
\hline Very Not Good & $0-200$ & 0 & 0.0 & & & \\
\hline \multirow[t]{2}{*}{ Total } & & 26 & 100 & & & \\
\hline & ategory Male & & & \multirow{2}{*}{ Mean } & \multirow{2}{*}{ Min } & \multirow{2}{*}{ Max } \\
\hline Response & Range & $\mathbf{F}$ & $\%$ & & & \\
\hline Very Good & 431 - to the top & 3 & 12.5 & \multirow{5}{*}{399.2} & \multirow{5}{*}{304} & \multirow{5}{*}{437} \\
\hline Good & $376-430$ & 12 & 50.0 & & & \\
\hline Enough & $311-375$ & 7 & 29.2 & & & \\
\hline Not Good & $251-310$ & 2 & 8.3 & & & \\
\hline Very Not Good & $0-250$ & 0 & 0.0 & & & \\
\hline Total & & 24 & 100 & & & \\
\hline
\end{tabular}

Table 5. The results of physical fitness of SMP 8 Denpasar students

\begin{tabular}{|c|c|c|c|c|c|c|}
\hline \multicolumn{4}{|c|}{ Category Female } & \multirow{2}{*}{ Mean } & \multirow{2}{*}{ Min } & \multirow{2}{*}{ Max } \\
\hline Response & Range & $\mathbf{F}$ & $\%$ & & & \\
\hline Very Good & 441 - to the top & 1 & 3.8 & \multirow{5}{*}{336.5} & \multirow{5}{*}{265} & \multirow{5}{*}{442} \\
\hline Good & $361-440$ & 9 & 34.7 & & & \\
\hline Enough & $281-360$ & 13 & 50.0 & & & \\
\hline Not Good & $201-280$ & 3 & 11.5 & & & \\
\hline Very Not Good & $0-200$ & 0 & 0.0 & & & \\
\hline \multirow[t]{2}{*}{ Total } & & 26 & 100 & & & \\
\hline & ategory Male & & & \multirow{2}{*}{ Mean } & \multirow{2}{*}{ Min } & \multirow{2}{*}{ Max } \\
\hline Response & Range & $\mathbf{F}$ & $\%$ & & & \\
\hline Very Good & 431 - to the top & 5 & 20.8 & \multirow{5}{*}{399.7} & \multirow{5}{*}{308} & \multirow{5}{*}{437} \\
\hline Good & $376-430$ & 10 & 41,7 & & & \\
\hline Enough & $311-375$ & 7 & 29.2 & & & \\
\hline Not Good & $251-310$ & 2 & 8.3 & & & \\
\hline Very Not Good & $0-250$ & 0 & 0.0 & & & \\
\hline Total & & 24 & 100 & & & \\
\hline
\end{tabular}


From table 5, which came from 50 respondents from the junior high school 8 Denpasar after they were obtained and the results using the SPSS 23 application program, the physical fitness of female students was in the dominant category quite good with a percentage of $50.0 \%$ (13 of 26 students) and has a mean value of 336.5 , a minimum score of 265, and a maximum score of 442. As for the male students physical fitness is in the dominant good category with a percentage of $41.7 \%$ (10 of 24 students) and has a mean value of 399.7 , a minimum score of 308 , and a maximum score of 437 .

From table 6, which came from 50 respondents from the junior high school 1 Denpasar after they were obtained and the results using the SPSS 23 application program, the physical fitness of female students was in the dominant category quite good with a percentage of $50.0 \%$ (13 of 26 students) and has a mean value of 334.5, a minimum score of 259, and a maximum score of 442 . As for the male students physical fitness is in the dominant good category with a percentage of $45.8 \%$ (11 of 24 students) and has a mean value of 397.6, a minimum score of 309 , and a maximum score of 436 .

From table 3-6, we can see that learning physical fitness activities based on traditional Balinese sports for students' physical fitness gets dominant results among several students who come from several schools. However, this has not been able to strengthen the existence of differences between schools that interpret learning physical fitness activities based on traditional Balinese sports games in schools, therefore inferential testing is carried out using MANOVA (tables 7-8) and independent sample t-test in table 9.

The manova test is used to see differences in the interpretation of learning physical fitness activities based on traditional Balinese sports games in schools for the physical fitness of students in Denpasar. The results of data analysis in table 7 on the interpretation of learning physical fitness activities based on traditional Balinese sports games in schools for physical fitness in Denpasar, the significance value is 0.000 or smaller than 0.025 with a significant level of 0.025 . So the data can be concluded that there is a significant difference in the average between participants in junior high school 1 Denpasar, participants in senior high school 3 Denpasar, participants in senior high school 8 Denpasar and participants in senior high school 9 Denpasar as measured by the ACSPFT test.

Table 6. Results of physical fitness of SMP 9 Denpasar students

\begin{tabular}{|c|c|c|c|c|c|c|}
\hline \multicolumn{4}{|c|}{ Category Female } & \multirow{2}{*}{ Mean } & \multirow{2}{*}{ Min } & \multirow{2}{*}{$\operatorname{Max}$} \\
\hline Response & Range & $\mathbf{F}$ & $\%$ & & & \\
\hline Very Good & 441 - to the top & 2 & 7.7 & \multirow{5}{*}{334.5} & \multirow{5}{*}{259} & \multirow{5}{*}{442} \\
\hline Good & $361-440$ & 8 & 30.8 & & & \\
\hline Enough & $281-360$ & 13 & 50.0 & & & \\
\hline Not Good & $201-280$ & 3 & 11.5 & & & \\
\hline Very Not Good & $0-200$ & 0 & 0.0 & & & \\
\hline \multirow[t]{2}{*}{ Total } & & 26 & 100 & & & \\
\hline & ategory Male & & & \multirow{2}{*}{ Mean } & \multirow{2}{*}{ Min } & \multirow{2}{*}{ Max } \\
\hline Response & Range & $\mathbf{F}$ & $\%$ & & & \\
\hline Very Good & 431 - to the top & 4 & 16.7 & \multirow{5}{*}{397.6} & \multirow{5}{*}{309} & \multirow{5}{*}{436} \\
\hline Good & $376-430$ & 11 & 45.8 & & & \\
\hline Enough & $311-375$ & 7 & 29.2 & & & \\
\hline Not Good & $251-310$ & 2 & 8.3 & & & \\
\hline Very Not Good & $0-250$ & 0 & 0.0 & & & \\
\hline Total & & 24 & 100 & & & \\
\hline
\end{tabular}

Table 7. The results of the interpretation of learning physical fitness activities based on traditional Balinese sports games at Junior High Schools in Denpasar City for students' physical fitness

\begin{tabular}{cccccc}
\hline \multicolumn{9}{c}{ MANOVA } \\
\hline & Value & F & Hypotesis df & Error df & Sig. \\
\hline Pillai's Trace & .970 & 352.811 & 3.000 & 19.000 & .000 \\
Wilks; Lambda & .019 & 352.811 & 3.000 & 19.000 & .000 \\
Hotelling's Trace & 22.397 & 352.811 & 3.000 & 19.000 & .000 \\
Roy's Largest Root & 22.397 & 352.811 & 3.000 & 19.000 & .000 \\
\hline
\end{tabular}


Related to the difference in the average between the four schools in Denpasar City for the interpretation of learning physical fitness activities based on traditional Balinese sports games in schools for students' physical fitness, to see a significant difference in the average success of learning interpretations of sports-based physical fitness activities Balinese traditional games at school to students' physical fitness which are carried out by participants are subjected to a Tukey post hoc test. Based on the results of the analysis that has been carried out, the results are as shown in table 8 below:

Table 8. Post hoc using Tukey in the interpretation of learning physical fitness activities based on traditional Balinese sports games in schools

\begin{tabular}{cccc}
\hline \multicolumn{3}{c}{ Interpretation of learning physical fitness activities } \\
\hline \multicolumn{3}{c}{ Tukey $^{\text {HSD }}{ }^{\text {a,b }}$} \\
\hline SEKOLAH & N & \multicolumn{2}{c}{ Subset for alpha = $\mathbf{0 . 0 2 5}$} \\
\cline { 3 - 4 } & & $\mathbf{1}$ & $\mathbf{2}$ \\
\hline Junior High School 1 & 50 & 26.7349 & 28.0876 \\
\hline Junior High School 3 & 50 & & 28.1086 \\
\hline Junior High School 8 & 50 & & 28.3091 \\
\hline Junior High School 9 & 50 & & .997 \\
\hline Sig. & & 1.000 & \\
\hline
\end{tabular}

Based on Table 8, it can be concluded that there is a significant difference in the group average between the first schools in the city of Denpasar. Furthermore, there is also a significant difference in the group mean between junior high school 3 denpasar, junior high school 8 denpasar and junior high school 9 denpasar. The smallest group average in junior high school 1 Denpasar City is 26.7349, followed by junior high school 3 with a group average of 28.0876, the largest average junior high school 8 Denpasar City is 28.1086, and the average largest junior high school 9 Denpasar, namely 28.3091.

From table 9, it can be seen that the value obtained (t count). The value of $t$ table can be seen in the t table with a significance value of 0.025 (2-sided test) with 200 degrees of freedom (df). In this study, the t table results were 1.98657. While the $\mathrm{t}$ value can be seen in table 9 . (Column t) is 14,317 for junior high school 1 Denpasar, 14,471 for junior high school 3 Denpasar, 14,599 for junior high school 8 Denpasar and 14,679 for junior secondary school 9 Denpasar. The criteria for testing the hypothesis in this study if the table value is smaller than the t count or the sig value obtained is smaller than the specified (0.025), then there is a difference [38]. Therefore, based on the results obtained, the $t$ count is greater than the $t$ table, there is a comparison between the two ration methods used. And reinforced by the significance value which is below 0.025 , namely 0.011 for junior high school 1 Denpasar, 0.013 for junior high school 3 Denpasar, 0.014 for junior high school 8 Denpasar and 0.016 for junior high school 1 Denpasar. So it can be concluded that there is a significant difference between the interpretation of learning physical fitness activities based on traditional Balinese sports games at schools to the physical fitness of students in junior high schools in Denpasar City.

Table 9. Results of the Independent sample t-test for students' physical fitness

\begin{tabular}{cccccccc}
\hline & & & \multirow{2}{*}{ S } & Df & Std. Deviation & \multicolumn{2}{c}{ 95\% confidence interval } \\
\cline { 5 - 8 } & & & & & Lower & Upper \\
\hline \multirow{2}{*}{ Junior High School 1 } & 14.317 & 200 & 0.011 & 2.37 & 12.139 & .4520 \\
& 14.317 & 76.426 & 0.011 & 1.73 & 11.541 & .5215 \\
\hline \multirow{2}{*}{ Junior High School 3 } & 14.471 & 200 & 0.013 & 2.43 & 12.346 & .4135 \\
& 14.471 & 77.831 & 0.013 & 1.82 & 11.994 & .5615 \\
\hline \multirow{2}{*}{ Junior High School 8 } & 14.559 & 200 & 0.014 & 2.51 & 12.296 & .4510 \\
\hline \multirow{2}{*}{ Junior High School 9 } & 14.559 & 77.142 & 0.014 & 1.88 & 11.971 & .5398 \\
\hline
\end{tabular}




\section{Discussion}

Based on the results that have been obtained (see table $3-6)$, that there are differences in the physical fitness of students from the implementation of learning physical fitness activities based on traditional Balinese sports games in junior high schools in Denpasar City.

Physical education and sports provide opportunities for students to be physically active while in school [39, 40]. And has many benefits, including developing motor skills, increasing physical fitness and self-esteem, and reducing the level of risk factors for heart disease and obesity, as well as maintaining and or improving student academic performance. Bevans wrote that giving sufficient time in physical education and exercise will increase the maximum energy use of students, this is a key contributor to the maintenance of a healthy body weight and physical fitness [41, 42]. This is supported by Silverman who states that the learning design is designed by the teacher, it is important to remember that each student needs a different amount of time and practice to acquire good skills and to be able to master the movements in higher skills. Conceptually, the mission of the physical education program and sports is education that is comprehensive, so that it is seen not only as related to the development of physical abilities, but broader than that, which includes dimensions, intellectually, mentally, socially and emotionally [43, 44].

The research results of García-López et al [45], explain that the play method approach can help improve student learning abilities and outcomes, the playing method can also build creativity in creating movement, build joy in a learning atmosphere, build togetherness in groups and build an image that pencak silat can be done with an atmosphere of joy and not loud. This is made clear from the results of Ilmah's research which states that the effect of the learning model using the teaching games for understanding method can increase learning motivation and in turn will significantly increase learning outcomes for elementary school students [46, 47].

Lots of new, interesting, and effective learning models have been developed for use by teachers. Among other things, direct instruction, personalized systems for instructional, cooperative learning, sport education, peer teaching, inquiry models, and tactical games [48-50]. Each of these learning models has its own characteristics in its application. It all depends on the teacher who will provide physical education and sports lessons, choose and apply which model is effective in order to achieve maximum learning outcomes for students [51, 52]. And form and improve good physical fitness for students. Increasing physical fitness is one of the actualizations of learning activities in order to support the creation of learning objectives. Coaching to improve physical fitness in students, especially in Strength. Endurance (Endurance).

Regarding the formation of physical fitness, Giriwijoyo
[53] further explained that the physical fitness of students will be formed if physical activity is carried out continuously for a long time and is sustainable. Based on this opinion, it can be concluded that to improve physical fitness, training is needed that involves physical activity with a fairly high intensity, dose, and frequency of exercise. Physical education is very compatible with the character of traditional games that make children play, which contains elements of cognitive, affective, psychomotor. Moreover, Physical Education for junior high schools, Physical Education for junior high schools in its implementation must generate student interest in learning Physical Education, so one of the learning methods is by using traditional games. Traditional games are physical activities carried out consciously and deliberately and using rules based on habits that have been passed down from generation to generation in a society [54-56]. Traditional games are games played by children with simple tools without machines, as long as the children are healthy, they can play. Traditional games are games full of values and noble norms that are useful for children to understand and find balance in life's challenges. Traditional games can be used as an alternative in junior high school physical education. Because traditional games contain elements of play, they are not bound by many rules as in competition. The purpose of traditional games, namely for entertainment, games for entertainment are useful for training the five senses, language, or other limbs [57-59]. Traditional games in this case can improve the balance of elementary school students [60-63]. Traditional games are often used as games that have native regional characteristics and are adapted to local cultural traditions. Its activities are carried out both regularly and occasionally with the intention of looking for entertainment and filling spare time after being separated from routine activities such as working for a living, going to school. In its implementation, traditional games can include elements of folk games and children's games into it. These findings are in line with the opinion of experts that students' physical fitness will be formed if physical activity is carried out continuously for a long and sustainable time [53]. In line with the above opinion, it can be concluded that to improve physical fitness training is needed which involves physical activity with a fairly high intensity, dose, and frequency of exercise.

\section{Conclusions}

The integration of local wisdom in this case is traditional games in learning very well, in addition to strengthening and introducing local culture, integrating traditional games into learning will make it easier for teachers to teach the learning they want to teach, especially in Physical Education subjects. Physical education is very compatible with the character of traditional games that make children play, which contains 
elements of cognitive, affective, psychomotor. Moreover, Physical Education for junior high schools, Physical Education for junior high schools in its implementation must generate student interest in learning Physical Education, so one of the learning methods is by using traditional games. Traditional games can be used as an alternative in junior high school physical education. Because traditional games contain elements of play, they are not bound by many rules such as competition which will improve students' physical fitness. Due to the physical fitness of students will be formed if, physical activity is carried out continuously for a long time and is sustainable.

The limitations of this study have not been measurements of the ability of blood circulation and heart work, flexibility, endurance, coordination, balance, speed, and agility of athletes (adolescents or those who are still in school) using Learning Physical Fitness Activities Based On Traditional Balinese Sports Games.

\section{Acknowledgements}

Thanks to all respondents who have been willing to be a sample in this study, so that this study can be completed as desired.

\section{REFERENCES}

[1] Maison., Astalini., Kurniawan, D. A., Perdana, R., Anggraini, L. (2019). The Phenomenon of Physicology Senior High School Education: Relationship of Students' Attitudes towards Physics, Learning Style, Motivation. Universal Journal of Educational Research. 7(10), 2199-2207.

[2] Astalini, Kurniawan, D. A., Darmaji, Ikhlas, M., Kuswanto, Perdana, R., Anggraini, L., \& Putra, I. (2020). Attitude and Self-confidence Students in Learning Natural Sciences: Rural and Urban Junior High School. Universal Journal of Educational Research, 8(6), 2569-2577.

[3] Syahrial., Asrial., Husni, S., Arsil. (2020). Attitudes, Self-Confidence, and Independence of Students in Thematic Learning. Universal Journal of Educational Research. 8(1), 162-168

[4] Tanti., Maison., Syefrinando, B., Daryanto, B., Salma. H. (2020). Students' self-regulation and motivation in learning sciences. Internaional Journal of Evaluation and Research in Education. 9(4), 865-873.

[5] Sum, R. K. W., Ma, M. S., Ha, A. S., Tang, T. M., Shek, C. K., Cheng, C. L., \& Kong, F. (2016). Action research exploring Chinese physical education teachers' value of physical education: from belief to culture. Asia Pacific Journal of Sport and Social Science, 5(1), 70-84.

[6] Sato, T., \& McKay, C. (2020). Japanese physical education graduate students' learning about research skill development. Curriculum Studies in Health and Physical Education, 11(1), 34-49.

[7] Sato, T., \& Haegele, J. A. (2017). Professional development in adapted physical education with graduate web-based professional learning. Physical Education \& Sport Pedagogy, 22(6), 618-632.

[8] Novak, J. D., \& Canas, A. J. (2006). The origins of the concept mapping tool and the continuing evolution of the tool. Information Visualization, 5, 175-184.

[9] Okamura, A. (2006). How do Japanese researchers cope with language difficulties and succeed in scientific discourse in English?: Interviews with Japanese research article writers. The Economic Journal of Takasaki City University of Economics, 48(3), 61-78.

[10] Makopoulou, K., \& Armour, K. (2011). Teachers' professional learning in a European learning society: The case of physical education. Physical Education and Sport Pedagogy, 16(4), 417-433

[11] Malik, M. (2016). Assessment of a professional development program on adult learning theory. Portal: Libraries and the Academy, 16(1), 47-70

[12] e Silva, R. L., Kanan, Y., Mirando, A. C., Kim, J., Shmueli, R. B., Lorenc, V. E., ... \& Campochiaro, P. A. (2017). Tyrosine kinase blocking collagen IV-derived peptide suppresses ocular neovascularization and vascular leakage. Science translational medicine, 9(373).

[13] Ma'mun, A., \& Mahendra, A. (2021). Sport and development in Indonesia. Sport and Development in Emerging Nations, 94.

[14] Yoda, I. K. (2008). Korelasi Antara Vo2 Maks Dengan Prestasi Belajar Siswa Kelas XI dan XII SMA Negeri 4 Singaraja Tahun Pelajaran 2008/2009. Laporan Penelitian. Singaraja: UNDIKSHA.

[15] Cai, Y., Zhu, X., \& Wu, X. (2017). Overweight, obesity, and screen-time viewing among Chinese school-aged children: national prevalence estimates from the 2016 Physical Activity and Fitness in China-The Youth Study. Journal of Sport and Health Science, 6(4), 404-409.

[16] Casey, A., \& Goodyear, V. A. (2015). Can cooperative learning achieve the four learning outcomes of physical education? A review of literature. Quest, 67(1), 56-72.

[17] Kingpum, P., Ruangsuwan, C., \& Chaicharoen, S. (2015). A Development of a Collaborative Blended Learning Model to Enhance Learning Achievement and Thinking Ability of Undergraduate Students at the Institute of Physical Education. Educational Research and Reviews, 10(15), 2168-2177.

[18] Bores-García, D., Hortigüela-Alcalá, D., Fernandez-Rio, F. J., González-Calvo, G., \& Barba-Martín, R. (2021). Research on cooperative learning in physical education: Systematic review of the last five years. Research quarterly for exercise and sport, 92(1), 146-155.

[19] Pill, S. (2007). Physical education-what's in a name?: A Praxis model for holistic learning in physical education. ACHPER Australia Healthy Lifestyles Journal, 54(1), 5-10.

[20] Gréhaigne, J. F., Wallian, N., \& Godbout, P. (2005). Tactical-decision learning model and students' practices. 
Physical Education and Sport Pedagogy, 10(3), 255-269.

[21] Silverman, S. (2011). Teaching for student learning in physical education. Journal of Physical Education, Recreation \& Dance, 82(6), 29-34.

[22] Pommerenke, R. L. (1971). Essential, Desirable Titles for Libraries of Schools Offering Professional Preparation in Physical Education: Basic Books in Physical Education. Journal of Health, Physical Education, Recreation, 42(4), 35-40.

[23] Vasconcellos, F., Seabra, A., Katzmarzyk, P. T., Kraemer-Aguiar, L. G., Bouskela, E., \& Farinatti, P. (2014). Physical activity in overweight and obese adolescents: systematic review of the effects on physical fitness components and cardiovascular risk factors. Sports medicine, 44(8), 1139-1152.

[24] Esteban-Cornejo, I., Tejero-González, C. M., Martinez-Gomez, D., del-Campo, J., González-Galo, A., Padilla-Moledo, C., ... \& Up \& Down Study Group. (2014). Independent and combined influence of the components of physical fitness on academic performance in youth. The journal of pediatrics, 165(2), 306-312.

[25] Mora-Gonzalez, J., Esteban-Cornejo, I., Cadenas-Sanchez, C., Migueles, J. H., Molina-Garcia, P., Rodriguez-Ayllon, M., ... \& Ortega, F. B. (2019). Physical fitness, physical activity, and the executive function in children with overweight and obesity. The Journal of pediatrics, 208, 50-56.

[26] True, L., Martin, E. M., Pfeiffer, K. A., Siegel, S. R., Branta, C. F., Haubenstricker, J., \& Seefeldt, V. (2021). Tracking of physical fitness components from childhood to adolescence: A longitudinal study. Measurement in Physical Education and Exercise Science, 25(1), 22-34.

[27] Gavilán-Carrera, B., Garcia da Silva, J., Vargas-Hitos, J. A., Sabio, J. M., Morillas-de-Laguno, P., Rios-Fernández, R., ... \& Soriano-Maldonado, A. (2019). Association of physical fitness components and health-related quality of life in women with systemic lupus erythematosus with mild disease activity. Plos one, 14(2), e0212436.

[28] Redondo-Tébar, A., Ruíz-Hermosa, A., Martínez-Vizcaíno, V., Cobo-Cuenca, A. I., Bermejo-Cantarero, A., Cavero-Redondo, I., \& Sánchez-López, M. (2019). Associations between health-related quality of life and physical fitness in 4-7-year-old Spanish children: The MOVIKIDS study. Quality of Life Research, 28(7), 1751-1759.

[29] Görner, K., \& Reineke, A. (2020). The influence of endurance and strength training on body composition and physical fitness in female students. Journal of Physical Education and Sport, 20, 2013-2020.

[30] Lisman, P. J., Sarah, J., Gribbin, T. C., Jaffin, D. P., Murphy, K., \& Deuster, P. A. (2017). A systematic review of the association between physical fitness and musculoskeletal injury risk: part 1-cardiorespiratory endurance. The Journal of Strength \& Conditioning Research, 31(6), 1744-1757.

[31] Sammito, S., Gundlach, N., \& Böckelmann, I. (2016). Correlation between the results of three physical fitness tests (endurance, strength, speed) and the output measured during a bicycle ergometer test in a cohort of military servicemen. Military medical research, 3(1), 1-6.

[32] Castillo, D., Raya-González, J., Sarmento, H., Clemente, F. M., \& Yanci, J. (2021). Effects of including endurance and speed sessions within small-sided soccer games periodization on physical fitness. Biology of Sport, 38(2).

[33] L. Cohen., L. Manion., \& K. Morrison. Research Methods in Education: Routledge. 2007

[34] J. W, Creswell. Research Design Qualitative, Quantitative, And Mixed Method Aproach. Singapore: SAGE Publications Asia-Pacific, 2012.

[35] Vaara, J. P., Fogelholm, M., Vasankari, T., Santtila, M., Häkkinen, K., \& Kyröläinen, H. (2014). Associations of maximal strength and muscular endurance with cardiovascular risk factors. International journal of sports medicine, 35(04), 356-360.

[36] Kyröläinen, H., Hackney, A. C., Salminen, R., Repola, J., Häkkinen, K., \& Haimi, J. (2018). Effects of combined strength and endurance training on physical performance and biomarkers of healthy young women. The Journal of Strength \& Conditioning Research, 32(6), 1554-1561.

[37] Görner, K., \& Reineke, A. (2020). The influence of endurance and strength training on body composition and physical fitness in female students. Journal of Physical Education and Sport, 20, 2013-2020.

[38] Cramer, D. Advanced quantitative data analysis. McGraw-Hill Education (UK). 2003

[39] Cai, J., Morris, A., Hohensee, C., Hwang, S., Robinson, V., \& Hiebert, J. (2018). The role of replication studies in educational research. Journal for Research in Mathematics Education, 49(1), 2-8.

[40] McEvoy, E., Heikinaro-Johansson, P., \& MacPhail, A. (2017). Physical education teacher educators' views regarding the purpose (s) of school physical education. Sport, Education and Society, 22(7), 812-824.

[41] Pühse, U., Gerber, M., Menginsen, W., \& Repond, R. M. (2005). Physical education in Switzerland. In U. Pühse \& M. Gerber (Eds.), International comparison of physical education: Concepts, problems, prospects (pp. 630-658). Oxford: Meyer \& Meyer Sport

[42] Bevans, K., Fitzpatrick, L. A., Sanchez, B., \& Forrest, C. B. (2010). Individual and instructional determinants of student engagement in physical education. Journal of Teaching in Physical Education, 29(4), 399-416.

[43] O’Sullivan, M. (2004). Possibilities and pitfalls of a public health agenda for physical education. Journal of Teaching in Physical Education, 23, 392-404

[44] Muros Ruiz, B., \& Fernández-Balboa, J. M. (2005). Physical education teacher educators' personal perspectives regarding their practice of critical pedagogy. Journal of Teaching in Physical Education, 24, 243-264

[45] García-López, L. M., Gutiérrez, D., Sánchez-Mora, D., \& Harvey, S. (2019). Teachers' use of teaching games for understanding in central Spain. Physical Education and Sport Pedagogy, 24(5), 463-477.

[46] Renshaw, I., Araújo, D., Button, C., Chow, J. Y., Davids, K., \& Moy, B. (2016). Why the constraints-led approach is not 
teaching games for understanding: A clarification. Physical Education and Sport Pedagogy, 21(5), 459-480.

[47] O'Leary, N. (2016). Learning informally to use the 'full version' of teaching games for understanding. European Physical Education Review, 22(1), 3-22.

[48] Fernandez-Rio, J. (2015). Models-based practice reloaded: Connecting cooperative learning and adventure education. Journal of Physical Education, Recreation \& Dance, 86(6), 5-7.

[49] Casey, A., \& MacPhail, A. (2018). Adopting a models-based approach to teaching physical education. Physical Education and Sport Pedagogy, 23(3), 294-310.

[50] Metzler, M. (2017). Instructional models in physical education. Taylor \& Francis.

[51] Tinning, R. (2006). Theoretical orientations in physical education teacher education. In D. Kirk, D. Macdonald, \& M. O'Sullivan (Eds.), The handbook of physical education (pp. 369-85). London: Sage.

[52] McInerney, P., Smyth, J., \& Down, B. (2011). 'Coming to a place near you?'The politics and possibilities of a critical pedagogy of place-based education. Asia-Pacific Journal of Teacher Education, 39(1), 3-16.

[53] Giriwijoyo, Santosa, Prof. HYS dkk. (2013).Ilmu Faal Olahraga (Fisiolo gi Olahraga)Bandung. PT. Remaja Rosda Karya

[54] Mawer, M. (1995). The effective teaching of physical education. London: Longman.

[55] Capel, S. (2005). Teachers, teaching and pedagogy in physical education. In K. Green \& K. Hardman (Eds.), Physical education: Essential issues (pp. 111-127). London: Sage.

[56] Melnychuk, N., Robinson, D. B., Lu, C., Chorney, D., \&
Randall, L. (2011). Physical education teacher education (PETE) in Canada. Canadian Journal of Education, 34(2), 148-168

[57] Asrial, Syahrial, Kurniawan, D. A, Chan, F., Nugroho, P., Pratama, R. A., Septiasari, R. (2019). Identification: The Effect Of Mathematical Competence On Pedagogic Competency Of Prospective Teacher. Humanities \& Social Science Reviews (HSSR). 7(4), 85-92

[58] Tanti, T., Kurniawan, D. A., Kuswanto, K., Utami, W., \& Wardhana, I. (2020). Science Process Skills and Critical Thinking in Science: Urban and Rural Disparity. Jurnal Pendidikan IPA Indonesia, 9(4), 489-498.

[59] Syahrial., Asrial., Kurniawan, D. A., Chan, F., Hariandi. A., Pratama, R. A., Nugroho. P., Septiasari. R. The Impact of Ethnoconstructivism in Social Affairs on Pedagogic Competences. International Journal of Evaluation and Researcn in Education (IJERE). 8(3), 409-416. 2019.

[60] Asrial., Syahrial., Kurniawan, D. A., Chan, F., Septianingsih, R., Perdana, R. (2019). Multimedia Innovation 4.0 in Education: E-Modul Ethnoconstrucivism. Universal Journal of Educational Research. 7(10), 2098-2107.

[61] Susanti, T., Damris, D., Maison, M., \& Tanti, T. (2020). Learning Environment and Motivation in Junior High School. Universal Journal of Educational Research, 8(5), 2047-2056.

[62] Maison., Syahrial., Syamsurizal., \& Tanti. Learning Environment, Students’ Beliefs, And Self-Regulation In Learning Physics: Structural Equation Modeling. Journal of Baltic Science Education, 18(3), 389-403. 2019.

[63] Asrial, A., Syahrial, S., Maison, M., Kurniawan, D. A., \& Perdana, R. (2020). A study of Traditional Games "Engklek" in Mathematics for Elementary School. Jurnal Ilmu Pendidikan, 26(1), 15-21. 